\title{
THE DESIGN OF EDUCATION EVALUATION SUBJECT USING GOOGLE CLASSROOM IN THE FACULTY OF TARBIYAH AND EDUCATION SCIENCE IAIN PALU
}

\author{
Erniati \\ IAIN Palu \\ Email:erniati@iainpalu.ac.id
}

\begin{abstract}
This research is aimed to reveal how Google classroom is used in the education evaluation subject and the lecture design of education evaluation using Google Classroom in the major of Islamic Education Studies, faculty of Tarbiyah and Education Science, IAIN Palu. This research uses descriptive qualitative. It concludes that the education evaluation lecture using Google classroom gives benefit to the students as well as to the lecturer due to the direct and clear communication between them, especially the materials given by the lecturer. Google classroom makes the learning process delightful for the class becomes really fun and students can explore the materials more exceedingly.
\end{abstract}

Keywords: Design; Education evaluation; Google classroom

\section{INTRODUCTION}

Evaluation is an assesment process of the learning output. Utilization of thechnology in the learning process allows the lecturer broaden their professional competence. This is expected to solve the problematic issue about less technology used in the class. One of the tecchnology suitable for delivering lectrure by lecturers in Education Evaluation subject is Google Classroom. This application is barely known to edicational figures in Indonesia. Google Classroom is believed to be the answer of the learning process in the class, for example the availability of time to conduct proper discussions about this matrials that is often limited.

A research conducted by Abdul Barir Hakim concluded that e-learning system such as E-Learning, Moodle, Google Classroom and Edmodo could potentially enhance students motivation. In the other hand, Pradana explains that Tools Google Classroom based class in the Project Based Learning method gives impact to students average result . Mahyuddin Ritonga et. al. in his research, in which he cited Filippova research by Nabiyev proved that online class, in this case Google Classroom, has many advantages. Firstly, it helps lecturer to inform students in that class or make an online test. Secondly, it allows students to submit assignments briefly without paper. Thirdly, it can be used as a discussion platform among students and lecturer themselves. Fourthly, students can share sources each other towards the feed. Lastly, lecturer can instruct, determine, and discuss to the students in real time online.

According to the research by Apairicio et. al, they indicated that students considered online class (e-learning) could increase productivity and facilitate their assignments. Therefore, online class gives a very positive feedback to the institution at large. A research done by Marfuatun et. al, shows that cooperative learning rate online is quite satisfying, but obviously requires material support such as computer and e-learning server.

The aim of this research is to observe the effectivity of Google Classroom in the subject of Education Evaluation, major of Islamic Education Studies, Faculty of Tarbiyah 
and Education Science of IAIN Palu, and to design an education evaluation lecture using Google Classroom, major of Islamic Education Studies, Tarbiyah and Education Science of IAIN Palu.

\section{RESEARCH METHOD}

This is a qualitative research with field observation. Data is collected through interview, observation, and documentation study. Interview is used to obtain direct information from the sources. Observation is used to complement information gained from interview and documentations, particularly in research problem, which are learning implementation, lecturers artefact, and the class, including the students themselves as an object of research. Documentation study is used to collect data and references required to design the learning in Google Classroom. Data analysis in this research is using a qualitative approach. After collcected through interview, observation and documentation, the data is then analyzed by: (1) data reduction; (2) data explanation; (3) conclusion/verification.

\section{RESEARCH RESULT}

a. The utilization of Google Classroom in the subject of Education Evaluation, major of Islamic Education Studies, faculty of Tarbiyah and Education Science IAIN Palu

This result is made by observation, documentation study, and interview with descriptive qualitative. The observation is applied to the Education Evaluation class. 10 groups of student are asked similar questions, but there are also specific questions asked to them for detailed information. There are five aspects of general and specific question.

The first question is about the online learning sources:

"In class, we use text book, learning module, Powerpoint file and handout. We are also given website to support our learning process such as Google Classroom. However, there are deadline to submit the onlie access to the lecturer."

This respondents answer highlighted that the learning sources used in the class are textbook, module, and internet website (Google Classroom). The other student has similar opininion to the PAI I class student above:

"The learning process of the subject of Education Evaluation has used various media, both regular and technology application. This helps us to understand the materials. The utilization of technology in the process of our learnings has been worked very well. The teacher uses various media such as Powerpoint slide, internet, and Google Classroom."

A more specific answer given by a PAI class student, who is a fifth semester student, saying that:

"Using Google Classroom is really helpful that we can learn not just from textbook, but also from Powerpoint, video learning, checking out the tasks given by the lecturer, and of course, we submit it without papers. "3

\footnotetext{
${ }^{1}$ Interview with students of PAI 1 Class, 12 July 2012, lecturers room, IAIN

${ }^{2}$ Interview with students of PAI 2 Class, 12 July 2012, lecturers room, IAIN

${ }^{3}$ Interview with students of PAI 3 Class, 12 July 2012, lecturers room, IAIN
} 
The answers above shows that the use of Google Classroom gives energy and motivation to the students to study more.

The second question is about learning sources that can develop learning product. The following answer is given by a fifth semester student:

"The Education Evaluation lecture using Google Classroom is very helpful for us to study, both for the learning process and accomplishing the tasks without necessarily require papers. It is also very efficient and flexible, can be done anywhere. The lecturer also can give us direct materials via online through this application, the Power Point, videos, and quizes as well. The only obstacle we encounter is the internet connection, every students must have different internet conncetion experience." 4

To conduct a daily evaluation, mid-semester evaluation, and final semester evaluation, the students obtain the sources shared in the Google Classroom. This is proved by an answer from a students from class 5 above:

"Our final result is determined by three aspects; cognitive, affective, and psychomotor. Daily quiz, mid semester evaluation, and final semester evaluation determines our value from the cognitive aspect. Thanks to Google Classroom, we can understand the materials and hence give us a good number of scores in this subject (Education Evaluation)." 5

Other student answers as follows:

"The students of PAI 4 said that we are very interested to the subject of Education Evaluation using Google Classroom application. It is because this application helps us to understand the materials and gives us new experience in using a cuttingedge technology in a learning process. Google Classroom is a flexible, effective and efficient application that can be accessed anywhere, hanytime, as long as the internet connection is available. "6

From the statements above we can tell that the Google Classroom is very useful for the Education Evaluation subject. It provides amenities for students understanding the materials. It is also an effective and efficient application for students.

The third question is about tasks submission. The answer is as follows;

We are recommended to submit our assignments via Google Classroom due to its effectiveness and efficiency. We need papers no more. ${ }^{7}$

This answer suggests students that they submit their assignments using Google Classroom. Another student answers:

"We sometimes submit our assignment via Google Classroom, but sometimes submit the hard copy as well, such as a task that requires cardboards, we submit it directly to the lecturer." 8

There are few tasks submitted via Google Classroom, but there are also requires them tu submit it in a hard copy form. However, besides Google Classroom, students also sometimes submit their assignments using Facebook and Whatsapp.

"We mostly use Google Classroom for submitting papers, book reviews and final exams. But some of us send it via Whatsapp and Facebook." 9

\footnotetext{
${ }^{4}$ Interview with students of PAI 4 Class, 12 July 2012, lecturers room, IAIN.

${ }^{5}$ Interview with students of PAI 5 Class, 12 July 2012, lecturers room, IAIN

${ }^{6}$ Interview with students of PAI 4 Class, 12 July 2012, lecturers room, IAIN

${ }^{7}$ Interview with students of PAI 6 Class, 12 July 2012, lecturers room, IAIN

${ }^{8}$ Interview with students of PAI 1 Class, 12 July 2012, lecturers room, IAIN

${ }^{9}$ Interview with students of PAI 6 Class, 12 July 2012, lecturers room, IAIN
} 
This method is usually taken for a simple task. For example giving answers from the quiz. The observation result and the collection of the secondary data from the students in which they are using Google Classroom media is;

The class management for Education Evaluation subject has been going very well. The students start the class by sitting on each chairs, listening to the class presence, material delivering process, and evaluation. The lecturer must provide their materials, learning media, and prepare the group class for discussion.

During the class, the students seemed to be proactive. They raised questions, held discussions, answered the given questions, and provided explanations for the whole class. Although there were still a few passive students in it.

The lecturer also used another learning strategy approach using the facility in the campus. The lecturer did not use teacher-centered strategy, but more to encouraging students to be cooperative and proactive in the class. The media used in the class are projector, laptop, powerpoint, internet, and Google Classroom.

Google Classroom is used as a media in order to make the students understand more about the materials. In Google Clasroom, students not only do they use textbook, but also using power point, accessing videos, checking the assignments, and submitting them without papers. With Google Classroom, students is not limited to the physical classroom only, it can be accessed out of the class time. It gives a new experience for students studying and understanding the materials.

b. The design of Education Evaluation lecture using Google Classroom, major of Islamic Education Studies, faculty of Tarbiyah and Education Science IAIN Palu

The researcher would like to breakdown the Education Evaluation lecture design used in the Google Classroom in the Faculty of Tarbiyah and Education Science of IAIN Palu.

1. Attendance

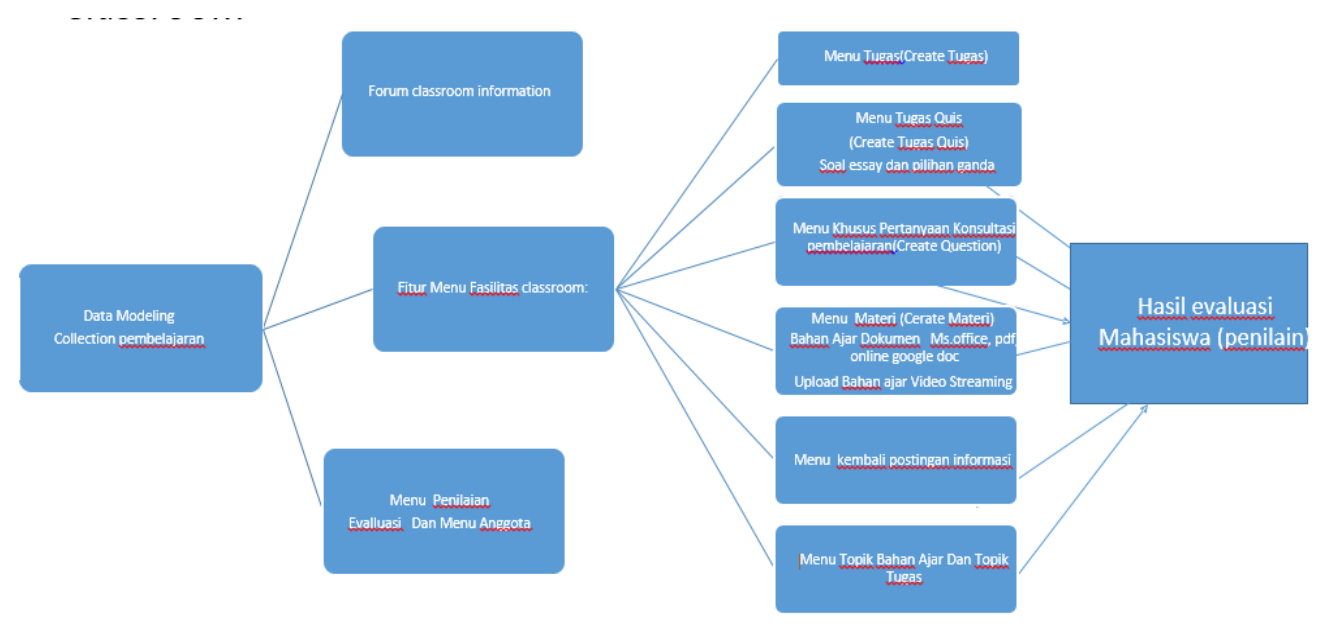

The figure above shows the attendance of students in Google Classroom PAI 1 class to PAI 10 class 
2. Stream

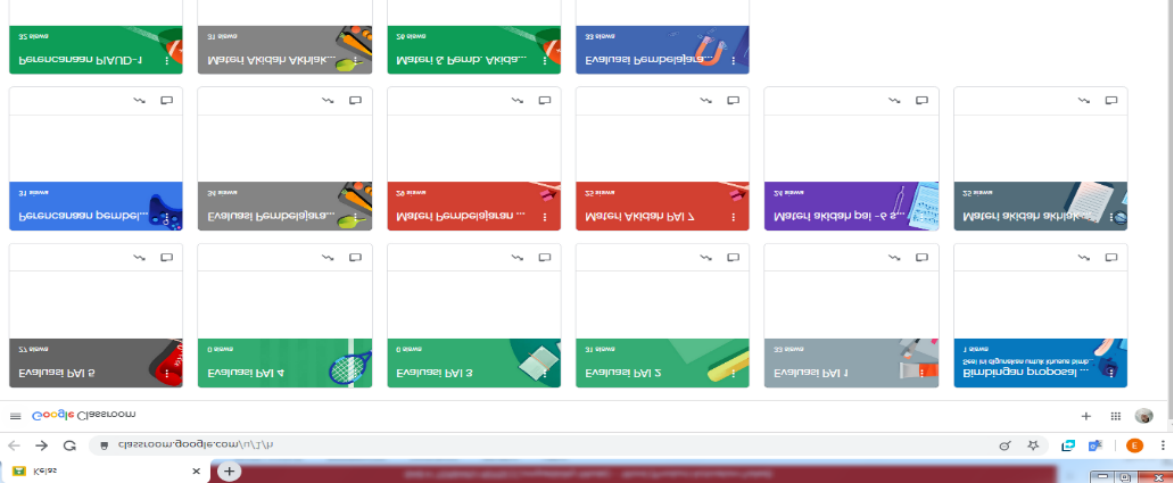

目 Tugas 1

Diposting tanggal 9 okt

Silahkan anda buat resume terkait pembahasan tentang konsep dasar

evaluasi (Pengertian) dan tujuan evaluasi pembelajaran PAI dengan

bahasa sendiri dikerjakan secara individu, dikirim dalam bentuk word.

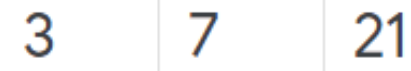

Batas pengumpulan tgl 15 Oktober 2019 jam 10 malam.

\begin{tabular}{l|l|l} 
Diserahkan Diberikan Dinilaì &
\end{tabular}

JANGAN SEKALI-KALI ANDA COPY PASTE RESUME TEMANNYA

KARENA DIAPLIKASI GOOGLE CLASSROOM LANGSUNG TERDEKSI

KALAU ADA KESAMAAN DALAM KATA =:

Lihat Tugas

The figures above shows the stream feature from Google Classroom for PAI class. This feature enables lecturer to send materials, assignments, quiz or other announcements delivered directly to the students attending the class.

3. Classmates

$\frac{\text { Guru Erni Labuaja }}{\text { (2) }}$

\begin{tabular}{|c|c|c|}
\hline \multicolumn{2}{|c|}{ Siswa } & $\stackrel{8}{8}$ \\
\hline$\square$ & Tindakan & $\hat{A Z}$ \\
\hline$\square$ & (6) adit firmansyah & $\vdots$ \\
\hline$\square$ & (B) Arifin & $\vdots$ \\
\hline$\square$ & (3) Asgandi A & $\vdots$ \\
\hline$\square$ & (8) Asria & $\vdots$ \\
\hline$\square$ & (2) Ayub $m$ Yasin & $\vdots$ \\
\hline$\square$ & A Azizah H Mahdang & $\vdots$ \\
\hline$\square$ & 8 Dinda Lestari & $\vdots$ \\
\hline
\end{tabular}


The figure shows the fiture of classmates in Google Classroom. This feature contains the list of students joining the class of PAI. Through this feature, all participants (lecturer and students) can build interactions via mail feature.

4. About

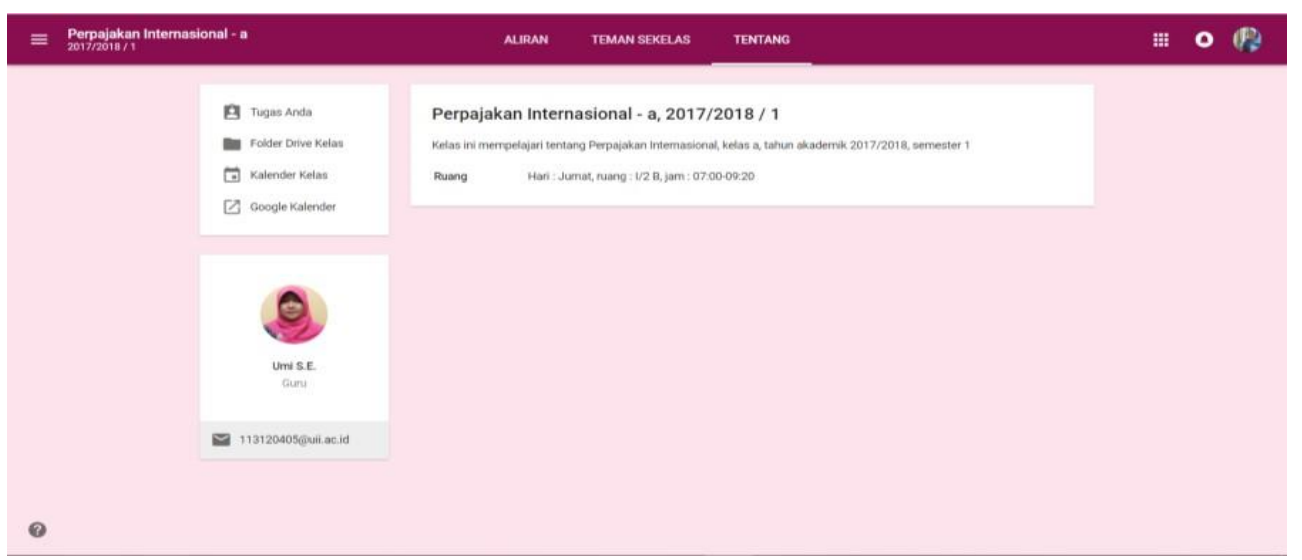

The figure is about fiture to describe the PAI class in the Google Classroom. The information could include subjects, classroom, timetable, and the names of the lecturers.

\section{Calendar}

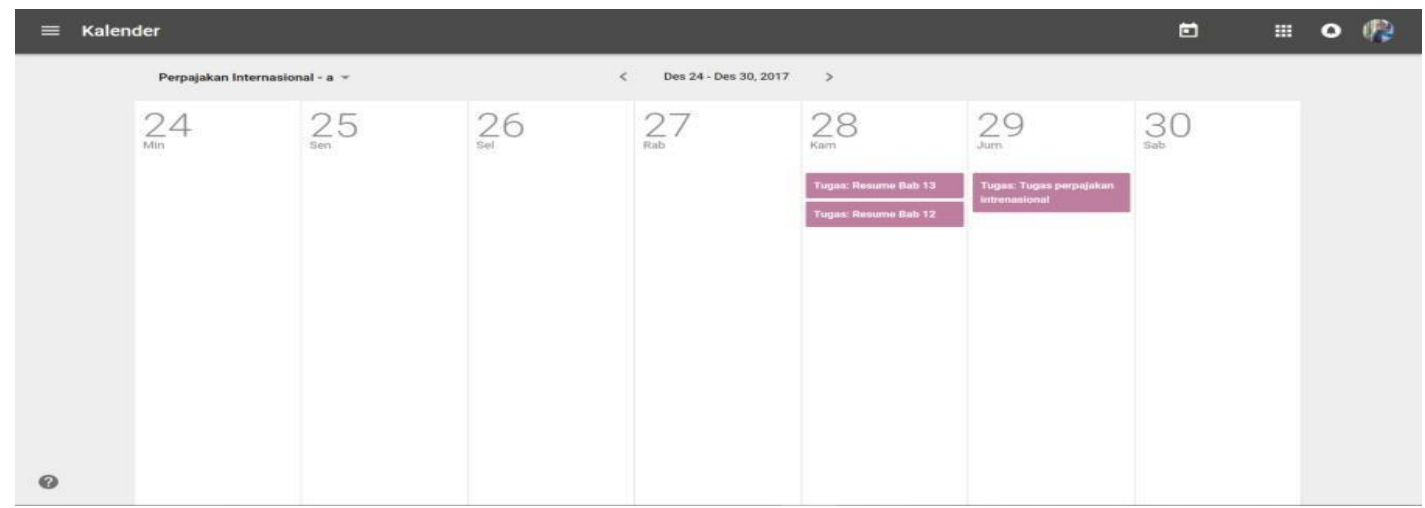

The figure above is the calendar feature in Google Classroom. Like the general calendar used to figure dates, it is also used for deadline reminder of the given assignments.

6. To-do

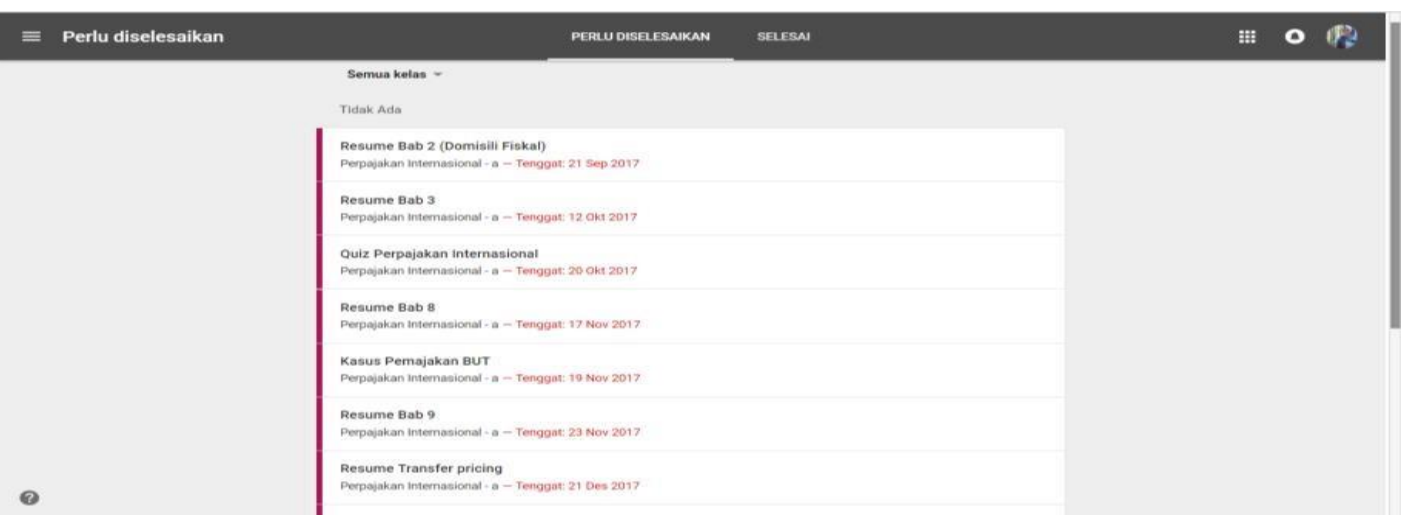


The figure above is the To-do feature of Google Classroom. This feature allows students to give deadline for their assignments determined by the lecturer beforehand.

7. Assignments

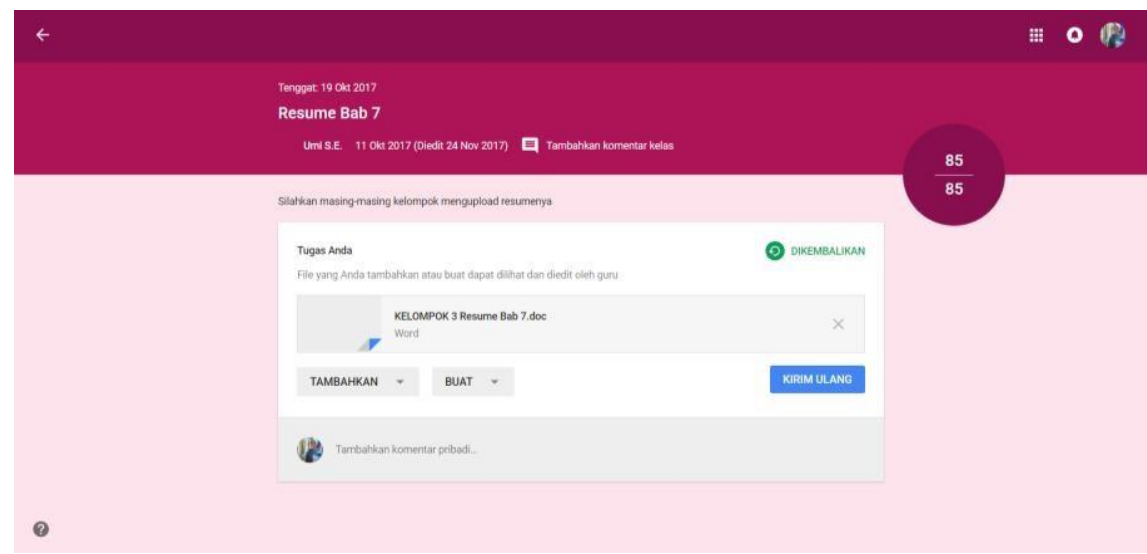

Above is an example of assignment from a lecturer in Google Classroom. This feature allows students to accomplish and submit their assignment to their lecturer based on the deadline time. Once submitted, the lecturer can later look into the assignments and redistributed again once it is finished.

There are many other features given installed in the Google Classroom, one example is a feature that enables students to check out their scores given by the lecturer as follows:

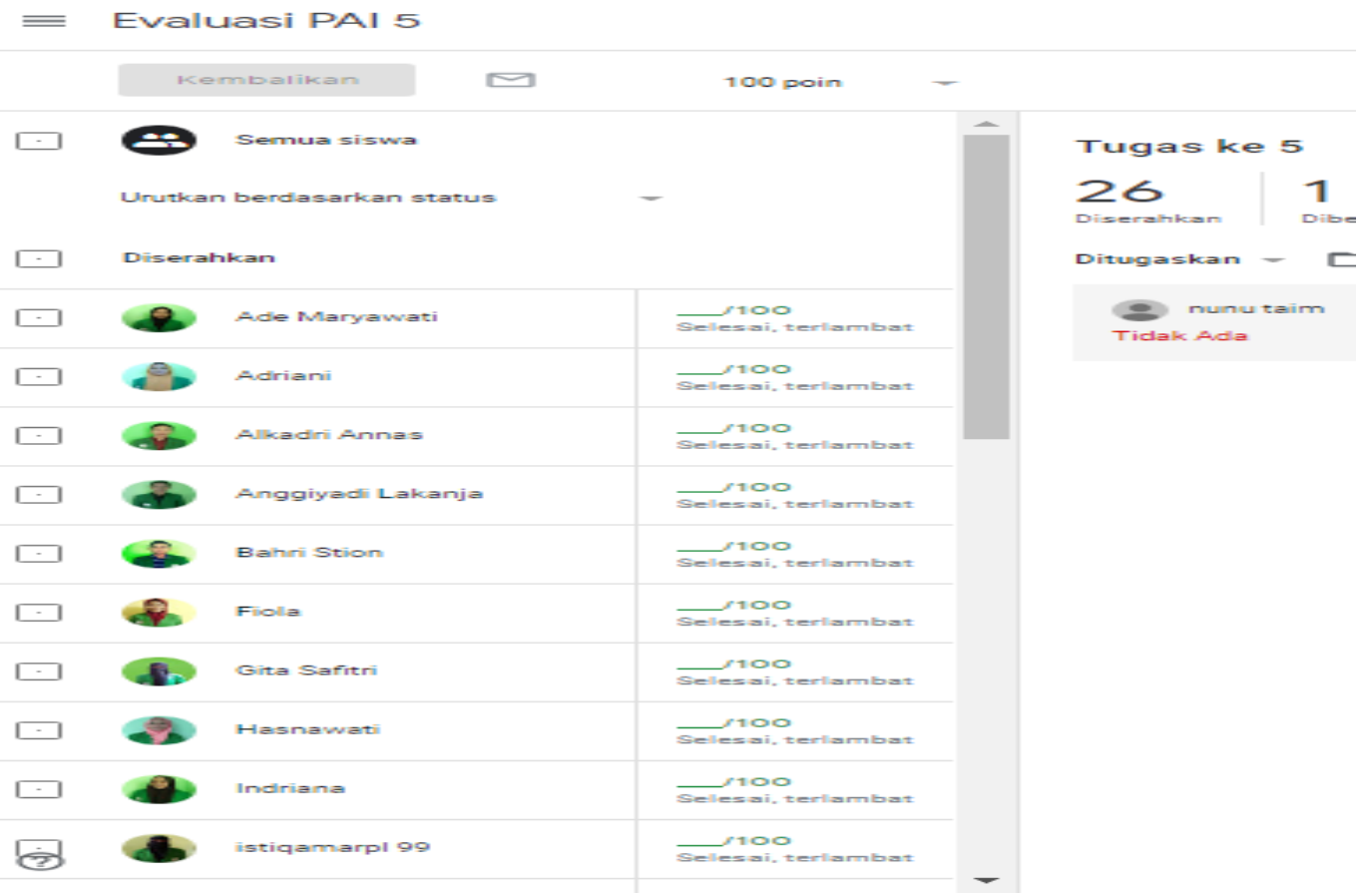

The figure above shows an information about the result of a subject evaluation. From here we can figure out whether the students pass the evaluation or otherwise. The lectrure, from this feature, can also remind students of their unaccomplished tasks. 


\section{CONCLUSION}

The subject of Education Evaluation via Google Classroom makes the lecture class easier because the application providess benefical features that allows students and lecuter build a comprehensive communication, especially those related to materials and the tasks. This advanced way of learning boosts motivation to the students to accomplish and submit their assignments just in time. Through this application, a learning process is no longer a wearisome and tedious to the students. They can even explore and do an experiment more intensively about the materials they study.

\section{BIBLIOGRAPHY}

Vicky Dwi Wicaksono dan Putri Rachmadyanti, "Pembelajaran Blended Learning Melalui Google Classroom di Sekolah Dasar", Prosiding Seminar Nasional Pendidikan PGSD UMS \& HDPGSDI Wilayah Jawa, 2017, p. 513-521.

Diemas Bagas Panca Pradana. Rina Harimurti. "Pengaruh Penerapan Tools Google Classroom pada Model Pembelajaran Project Based Learning terhadap Hasil Belajar Siswa", Jurnal IT-Edu, Volume 02 Nomor 01 Tahun 2017, 5967. ${ }^{1}$ Filippova Tatyana. "Priority Fields of E-Learning Development in Russia." Procedia - Social and Behavioral Sciences. Elsevier B.V.:348-53. https://doi.org/10.1016/j.sbspro.2018, p. 10.

Aparicio Manuela, Fernando Bacao, and Tiago Oliveira. "Grit in the Path to E-Learning Success." Computers in Human Behavior 66. Elsevier Ltd:388-99. https://doi.org/10.1016/j.chb. 2018.10.009.

Marfuatun E Widjajanti, and Suwardi. "Pengembangan Metode Pembelajaran Kooperatif Secara Online Pada Kuliah Kimia Fisika II." Jurnal Pendidikan Matematika Dan Sains, 2017, h. 125.

John Bailey dkk, Google Classroom Implementation Guide, Atlanta, Georgia: Digital Learning Now, 2017, h. 4

Noordin Asnawi, "Pengukuran Usability Aplikasi Google Classroom Sebagai E-learning Menggunakan USE Questionnaire (Studi Kasus: Prodi Sistem Informasi UNIPMA)", Research : Journal of Computer, information system, \& technology management, Vol. 1, No. 2, 2018, 17-21.

Sheshneva, Marianna dkk, Learning to Use Learning During Medical School and Residency, Journal of the Medical Library Association; August 2018; p. 263-270.

Abdul Barir Hakin, Efektifitas Penggunaan E- Learning Mododle, Google Classroom and Edmodo, I-STATEMENT, Volume 2 Nomor 1, Januari 2017.

Gary Gomes, Google Classroom, Student Self Efficacy And Faculty An Interpretative Phenomenological Analysis, Dissertation, College of Professional Studies Northeastern University Boston, Massachusetts, 2016. 